\title{
Fabrication and Characterization of Core-Shell
}

\section{Magnetic Chitosan Nanoparticles as a Novel carrier for Immobilization of Burkholderia cepacia Lipase}

\author{
Arezoo Ghadi ${ }^{1,2}$, Fatemeh Tabandeh ${ }^{1 *}$, Soleiman Mahjoub ${ }^{3}$, Afshin Mohsenifar ${ }^{4}$, \\ Farid Talebnia Roshan ${ }^{2}$ and Razieh Shafiee Alavije ${ }^{1}$ \\ ${ }^{1}$ Department of Industrial and Environmental Biotechnology, National Institute of Genetic Engineering and Biotechnology (NIGEB), Tehran, Iran \\ ${ }^{2}$ Faculty of Chemical Engineering, Noshirvani University of Technology, Babol, Iran \\ ${ }^{3}$ Department of Biochemistry \& Biophysics, Faculty of Medicine, Babol University of Medical Sciences, Babol, Iran \\ ${ }^{4}$ Department of Toxicology, Faculty of Medical Sciences, Tarbiat Modares University, Tehran, Iran
}

\begin{abstract}
In this study, the chitosan magnetic core-shell nanoparticles (CMNPs) was synthesized and then used as a support for immobilization of lipase. The characteristics of CMNPs, including morphology, topography and spectra type before and after immobilization were determined. The scanning electron micrographs of the CMNPs showed that they were approximately uniform spheres and the distribution chart indicated that the particles have the mean diameter of $100 \mathrm{~nm}$. Kinetic parameters of $K_{m}$ and $V_{m}$ were calculated as $1.07 \mathrm{mM}$ and $29.43 \mathrm{U} / \mathrm{mg}$ for free $B$. cepacia lipase and $1.29 \mathrm{mM}$ and $25.82 \mathrm{U} / \mathrm{mg}$ for immobilized lipase on CMNPs, respectively. The activity of immobilized lipase was $32 \mathrm{U} / \mathrm{mg}$ under optimum temperature and $\mathrm{pH}$. CMNP's were used in trasesterification reaction in order to evaluate the activity of the immobilized enzyme compared to the free enzyme. Immobilization of lipase on CMNPs improved stability and total relative activity of the enzyme. It could be concluded that CMNPs be considered as a suitable carrier for enzyme immobilization.
\end{abstract}

Key words: magnetite nanoparticles, core-shell, chitosan, lipase, immobilization

\section{INTRODUCTION}

In recent years, core-shell nanoparticles are finding widespread application in all fields. The necessity to shift to core/shell nanoparticles is the improvement in the properties. At a large scale, the industries that make most use of these materials are the chemical, mechanical, electronics and biomedical industries. They are used as catalysts, modifiers, fillers, thermal and mechanical property enhancers, sensor material due to high sensitivity to slight changes in parameter. The biomedical industry is the potential play field today ${ }^{1,2)}$. In some of nanocomposite, the core is coated with a polymeric layer because the polymeric will endow the hybrid structure with an additional function on top of the function/property of the core, hence synergistically emerged functions can be raised ${ }^{3}$. Polymeric core/ shell nanocomposite is the most commonly used transplant material. Core-shell structures serve a wide category of drug delivery application. The particles are biocompatible, have the ability to be conjugated to molecules without af- fecting the core and also can be used to encapsulate drugs $^{1)}$. Various micro/nano carriers, particularly nanoparticles and nanofibers, have become available for enzyme immobilization ${ }^{4,5)}$. Typically, smaller particles provide a larger surface area for the attachment of enzymes ${ }^{6)}$ and a shorter diffusional path for the substrates. Thus, nanostructured carriers have been utilized as carriers for enzyme immobilization ${ }^{7}$.

Chitosan as a biodegradable polymer was extensively used in several fields such as metal adsorption, enzyme immobilization and controlled drug delivery ${ }^{8)}$. The amino groups in polymeric structure of chitosan have made it as a high capacity biological carrier for enzyme immobilization. Furthermore, chitosan is one of the best biological absorbent for the removal of heavy metals from industrial waste water treatment. Its various forms (membrane, powder, fiber and prose) especially in nano size increase the adsorption rate ${ }^{9-12)}$.

Lipases (E.C. 3.1.1.3) are hydrolase enzymes with a wide

\footnotetext{
*Correspondence to: Fatemeh Tabandeh, Department of Industrial and Environmental Biotechnology, National Institute of Genetic Engineering and Biotechnology (NIGEB), Tehran, Iran

E-mail: taban_f@nigeb.ac.ir

Accepted December 10, 2014 (received for review October 21, 2014)
}

Journal of Oleo Science ISSN 1345-8957 print / ISSN 1347-3352 online

http://www.jstage.jst.go.jp/browse/jos/ http://mc.manusriptcentral.com/jjocs 


\section{A. Ghadi, F. Tabandeh and S. Mahjoub et al.}

industrial application, including food industry, detergent formulation and pharmaceutical industry ${ }^{13,14)}$. Recently, the expanding interest in lipase mainly lies on its application as a catalyst in transesterification reaction for biodiesel production. Although this reaction can be catalyzed by base or acid, but both of them have many disadvantages ${ }^{15,16)}$. Lipase is a suitable substitute for both because lipase-catalyzed transesterification has many advantages such as decreasing process stages in biodiesel fuel production, low operation temperature and easy separation of the glycerol by-product without complicated operational stages. But production, separation and purification of lipase are expensive. Lipase activity and stability are improved and this can be used repeatedly by using enzyme immobilization. Therefore lipase can be used more economically and efficiently in aqueous and non-aqueous solvents. Lipases have been immobilized on different carriers to catalyze a variety of reactions ${ }^{13-19)}$.

Magnetic carriers can be used as a superior support material because they are easily separated from reaction medium, and their use decreases the operating cost. The most important applications of magnetic carriers are in wastewater treatment, affinity chromatography, and immobilization of enzymes or other biomolecules ${ }^{20,21)}$. The magnetic nano particles may be a better choice because the magnetic separation is easier and generally avoids loss of particles ${ }^{22)}$. The advantages of magnetic nano-carriers are high mechanical resistance, good thermal stability and resistance against chemical and microbial degradation. For selective binding of magnetic nano particles with crosslinking techniques by glutaraldehyde connections, the particles are placed in core and chitosan polymer covers the magnetic core through a coating process ${ }^{2}$. These magnetic nanoparticles can be used as a powerful carrier for enzyme immobilization.

The main goal of this project is synthesis of magnetitechitosan (core-shell) nanoparticles and immobilization of lipase on CMNPs carrier which can be applied as a catalyst. For this reason, the CMNPs were synthesized and lipase was immobilized on the particles. The characteristics of the particles before and after enzyme immobilization were determined. The activity of free and immobilized lipase was compared as well.

\section{MATERIALS AND METHODS}

\subsection{Materials}

Lipase (from Burkholderia cepacia) and chitosan polymers $\left(\mathrm{M}_{\mathrm{w}}=200 \mathrm{kDa}\right.$, deacetylating degree $\left.65 \%\right)$ were purchased from Sigma-Aldrich. Aqueous acetic acid (Merck, Germany) solution was used as solvent for the chitosan polymers and glutaraldehyde(Merck, Germany) was employed as cross-linker. Para-nitrophenyl palmitate
(pNPP), triton X-100, Arabic gum, $\mathrm{FeCl}_{3} \cdot 6 \mathrm{H}_{2} \mathrm{O}, \mathrm{FeSO}_{4}$. $7 \mathrm{H}_{2} \mathrm{O}, \mathrm{NH}_{3}$, methanol tri-sodium citrate, hydrochloric acid $(\mathrm{HCl})$ and sodium hydroxide $(\mathrm{NaOH})$ were supplied by Merck (Germany). Rice bran oil and soybean oil were prepared from domestic market and Novozym 435 was purchased from Novo Nordisk A.S., Denmark-Tehran Office. Deionized water was used in all the experiments.

\subsection{Synthesis of Magnetic $\mathrm{Fe}_{3} \mathrm{O}_{4}$ Nanoparticles}

For preparation of $7.2 \mathrm{mM} \mathrm{Fe}$ (III) and $3.6 \mathrm{mM} \mathrm{Fe}$ (II) solutions, $0.194 \mathrm{~g} \mathrm{Fe}$ (III) and $0.1 \mathrm{~g} \mathrm{Fe}$ (II) were dissolved in distilled water and then their volume were reached to 100 $\mathrm{ml}$ separately. The amount of $25 \mathrm{ml}$ from each solution was added to an oxygen free container while $\mathrm{N}_{2}$ was flown in it. The solution was stirred for $30 \mathrm{~s}$ and then, $10 \mathrm{ml} \mathrm{NH}_{3}$ was quickly added to solution. $\mathrm{pH}$ was adjusted at 9 . After 45 min, the prepared nanoparticles were stuck to the magnet and were separated easily. Synthesized magnet nanoparticles were washed with distilled water at $\mathrm{pH} 7$, and dried at $37-40^{\circ} \mathrm{C}$. The amount of $100 \mathrm{ml}$ tri-sodium citrate solution $(0.158 \mathrm{~g}, 5.4 \mathrm{mM})$ was prepared. $0.01 \mathrm{~g}$ magnet nanoparticles were dissolved in $25 \mathrm{ml}$ distilled water and combined with $25 \mathrm{ml}$ tri-sodium citrate solution. The result solution was sonicated for $20 \mathrm{~min}^{2}$.

\subsection{Synthesis of Chitosan Magnetic Nanoparticles (CMNPs)}

One gram chitosan was dissolved in $100 \mathrm{ml}$ of $1 \%$ acetic acid solution and stirred at $1000 \mathrm{rpm}$ for $30 \mathrm{~min}$ at room temperature until the solution became clear. The resulting solution was sonicated (Amplitude 60, Cycle 0.5) and then titrated by addition of hydrochloric acid or sodium hydroxide solution adjusted to $\mathrm{pH} 5$ and filtered $(0.2 \mu$ mesh). For coating process, $1 \mathrm{ml}$ nanomagnet solution was added to 15 $\mathrm{ml}$ distilled water and sonicated for $5 \mathrm{~min}$. Then, chitosan solution was added and sonicated for $5 \mathrm{~min}$. The resulting solution was clear.

\subsection{Immobilization of lipase on CMNPs}

Glutaraldehyde ( $480 \mu \mathrm{l}, 25 \mathrm{v} / \mathrm{v} \%)$ was added to $5 \mathrm{ml}$ of double distilled water and $2 \mathrm{ml}$ CMNPs solution was added under vigorous stirring. The excess of glutaraldehyde was removed by washing three times using centrifugation $(10,000 \times \mathrm{g}, 20 \mathrm{~min})$ and then placed in ice. One mg lipase $\left(50 \mathrm{IU} \mathrm{mg}^{-1}\right.$ ) was dissolved in $10 \mathrm{ml}$ phosphate buffer at $\mathrm{pH}$ 7.4 and placed in ice. Under constant stirring at $1000 \mathrm{rpm}$, the cheered CMNPs-glutaraldehyde solution was added to the enzyme solution drop wise in $1 \mathrm{~min}$. In this experiment, lipase was immobilized on the surface of CMNPs by cross linking and Schiff-base method ${ }^{23)}$. Scheme 1 presents the preparation of CMNPs and lipase immobilization.

\subsection{Electron Microscopy}

The samples were dipped into liquid nitrogen for $10 \mathrm{~min}$, and then freeze dried for $7 \mathrm{~h}$ in the freeze drier(EMITECH, 


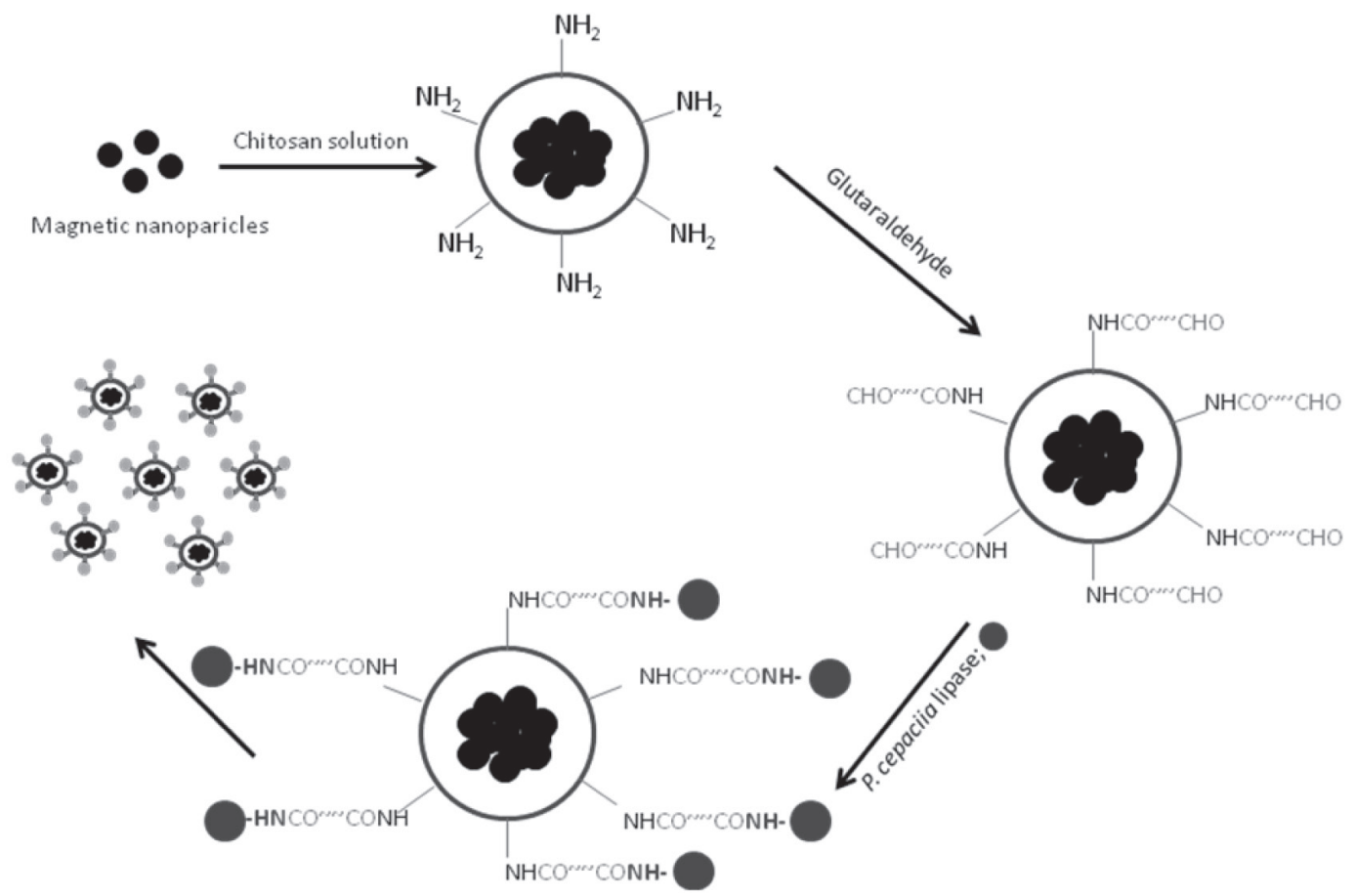

Scheme 1 Schematic illustration for synthesis of CMNPs and lipase immobilization.

model IK750, Cambridge, UK). They were fixed on the aluminum stub and coated with gold palladium by Polaron machine (model SD515, EMITECH, Cambridge, UK) at 20 nm coating thickness. Finally the sample was examined by scanning electron microscopy (SEM) using Stereoscan (model S360 brand SEM - Leica Cambridge, Cambridge, UK). The size and morphology of CMNPs with and without lipase were observed by transmission electron microscopy (TEM) (Philips CM200 EFG, FEI Company, Eindhoven, Netherlands).

\subsection{Atomic Force Microscopy (AFM)}

AFM pictures were taken using an Autoprobe CP Research AFM system (model AP- 2001, Thermomicroscopes, USA). Samples were prepared by spreading a drop of nanoparticle solution on a degreased glass plate uniformly.

\subsection{Fourier Transform Infrared Spectroscopy (FTIR)}

Infrared spectra were recorded on a Rayleigh WQF-510 Fourier transform instrument. The samples were $B$. cepacia lipase, chitosan magnetic nanoparticles and chitosan magnetic nanoparticles after lipase immobilization, respectively.

\subsection{Transestrification reaction}

The reaction mixture contained $50 \mathrm{mg}$ oil, $0.9 \mathrm{w} / \mathrm{w}$ free or immobilized enzymes to oil, and different molar ratio of 3:1 methanol to oil by 3-stepwise addition strategy at 24, 48 and $72 \mathrm{~h}$, and volume ratio of $2: 1$ tert-butanol to oil. The screw-capped bottles were incubated at $37^{\circ} \mathrm{C}$ on reciprocal shaker with $300 \mathrm{rpm}$ for $72 \mathrm{~h}$.

\subsection{Analytical methods}

The fatty acid content of oil was measured by gas chromatography $(\mathrm{GC})^{21)}$. The methyl ester present in the reaction mixture was analyzed using a GC-3800CP gas chromatography system(Varian Crop., Netherlands) connected to a cpsil-5CB capillary column $(0.32 \mathrm{~mm} \times 30 \mathrm{~m}$, Varian, Netherland). Methyl heptadecanoate was used as an internal standard, $5 \mathrm{mg}$ of which was mixed with $50 \mathrm{mg}$ of crude product and $1 \mathrm{ml}$ of hexane. Subsequently, $1 \mu \mathrm{l}$ of the resulting solution was injected into the GC. The column temperature was held at $150^{\circ} \mathrm{C}$ for $1 \mathrm{~min}$ and then subsequently raised to $200^{\circ} \mathrm{C}$ at the rate of $20^{\circ} \mathrm{C} / \mathrm{min}$, to $207^{\circ} \mathrm{C}$ at the rate of $1{ }^{\circ} \mathrm{C} / \mathrm{min}$, to $300^{\circ} \mathrm{C}$ at a rate of $30^{\circ} \mathrm{C} / \mathrm{min}$ and finally maintained at this temperature for $24 \mathrm{~min}$. The temperatures for the injector and flame ionization detector (FID) were set at 270 and $300^{\circ} \mathrm{C}$, respectively.

The activity of the free and immobilized lipase was determined by spectrophotometric determination of the hydrolysis products p-nitrophenyl palmitate (pNPP), a wellknown procedure ${ }^{24)}$. Briefly, Solution A contained pNPP dissolved in $10 \mathrm{ml}$ of 2-propanol to concentrations of 16.5 $\mathrm{mM}$, with a sonicator for $6 \mathrm{~min}$ at room temperature. Solution B for the pNPP assay consisted of $50 \mathrm{mM}$ Tris HCI buffer ( $\mathrm{pH} 8.0)$ containing $0.4 \%(\mathrm{w} / \mathrm{v})$ Triton $\mathrm{X}-100$ and $0.1 \%(\mathrm{w} / \mathrm{v})$ gum Arabic. The reaction mixture consisting of 1 part solution A and 9 parts solution B was prepared fresh before the assay. A $100 \mu \mathrm{l}$ of an appropriate dilution of the enzyme solution was added to $900 \mu$ l of the reaction 
mixture. Absorbance was measured at $410 \mathrm{~nm}$ on a UV-Vis spectrophotometer (Jenway 6505, UK). Standard solutions of p-nitrophenol(pNP) were prepared at $0.05-5 \mathrm{mM}$ to prepare a calibration curve. One unit of lipase activity was defined as the amount of enzyme that liberated $1 \mu \mathrm{mol} p$ nitrophenol from pNPP, per min.

For protein determination, concentration of total protein was assayed according to the method of Bradford with Coomassie Brilliant Blue G-250 and BSA was used as the standard protein ${ }^{25)}$.

In order to determine the optimal $\mathrm{pH}$ of the enzyme, the enzyme assay was carried out at different $\mathrm{pH}$ values (5.08.0) prepared by phosphate buffer at $40^{\circ} \mathrm{C}$. Optimal temperature was determined by a standard activity assay in the temperature range from $20^{\circ} \mathrm{C}$ to $60^{\circ} \mathrm{C}$.

The kinetic parameters of $\mathrm{K}_{\mathrm{m}}$ and $\mathrm{V}_{\mathrm{m}}$ values of free and immobilized enzyme were obtained according to Lineweaver-Burk equation:

$$
\frac{1}{V}=\left(\frac{K_{\mathrm{m}}}{V_{\mathrm{m}}}\right) \frac{1}{[S]}+\frac{1}{V_{\mathrm{m}}}
$$

\section{RESULTS AND DISCUSSION}

\subsection{Characterization of CMNPs}

The morphology of the prepared nanoparticles was examined with TEM, SEM and AFM. As shown in Scheme 1, chitosan coats the magnetic nanoparticles, so it is expected to sphere or sphere like shapes are observed. TEM images shown in Fig. 1, clearly indicated that the magnetic nanoparticles had spherical or ellipsoidal. This figure also showed that the produced nanoparticles had a reasonable size distribution.

The scanning electron micrographs of the CMNPs showed that they are approximately uniform spheres (Fig. 2). Wu et al (2009) fabricated the magnetic chitosan nanoparticles by crosslinking of chitosan by sodium tripolyhosphate and then precipitation of $\mathrm{Fe}(\mathrm{OH})_{2}$ in presence of $\mathrm{NaOH}$. They showed that these particles had nanometric spherical shapes ${ }^{31}$.

AFM picture indicated that no hair cracks or heterogeneity appears on the surface of chitosan nanoparticles (Fig. 3). The size distribution of nanoparticles was measured by Zetasizer. Figure 4 showed that the particles had the size range of 20-250 nm with average size of $100 \mathrm{~nm}$. It seems that chitosan was aggregated physically, as observed in TEM micrographs, may be due to their small size and high surface energy.

As shown in Scheme 1, the surfaces of chitosan has amine groups which reacts with one of the aldehyde groups of the cross linker, glutaraldehyde. After enzyme immobilization, the amine groups of enzyme molecules are bound to another aldehyde group of glutaraldehyde through $\mathrm{C}=\mathrm{N}$ bonds. FT-IR spectra for CMNPs with and without enzyme
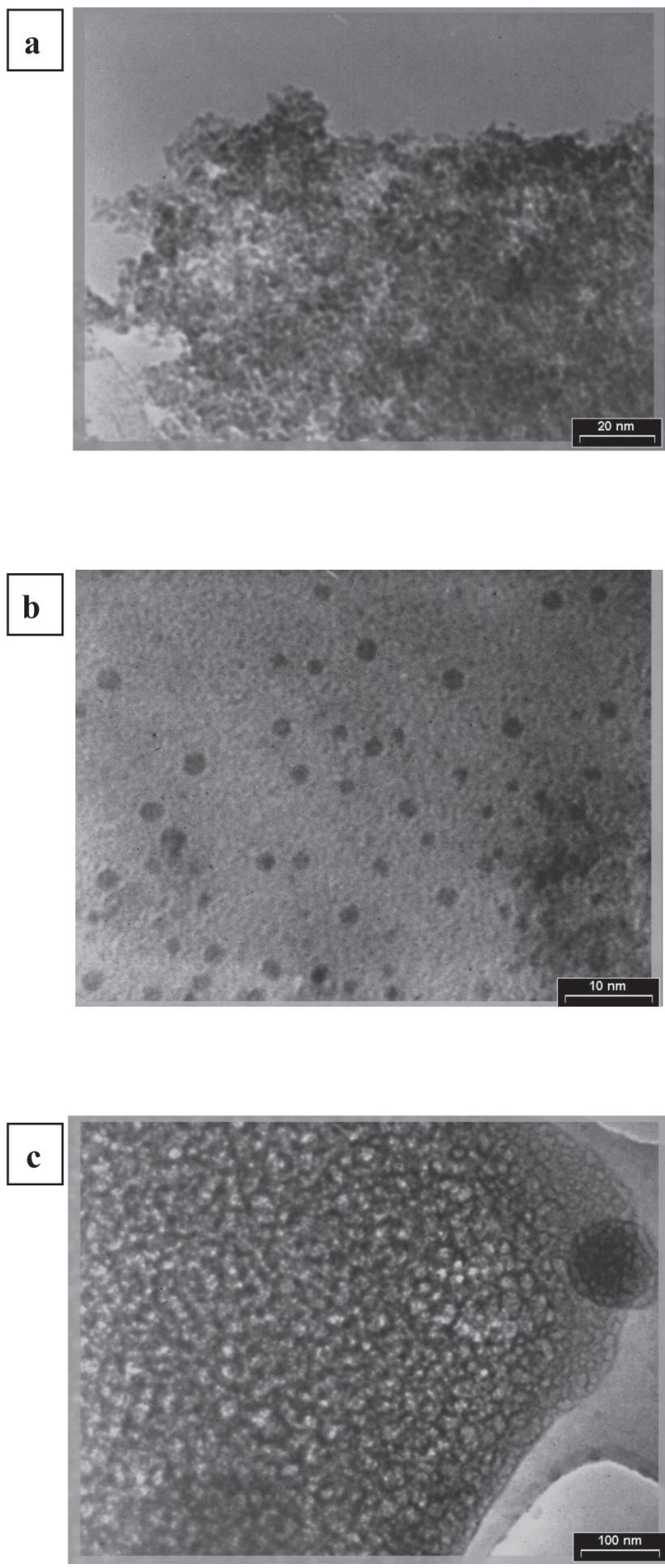

Fig. 1 TEM images of a) magnetic nanoparticles, b) chitosan magnetic nanoparticles, c) chitosan magnetic nanoparticles with immobilized lipase.

are shown in Fig. 5. For the chitosan magnetic nanoparticles, the broad absorption peak at $3440 \mathrm{~cm}^{-1}$ was described to the hydroxyl stretching group and also amine stretching 


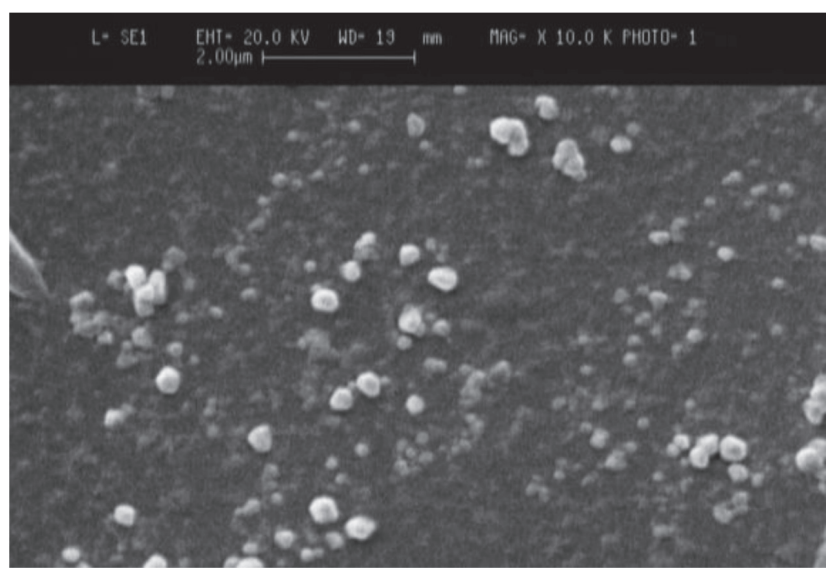

Fig. 2 SEM micrograph of CMNPs.

group of chitosan (spectra 5a). The absorption peak at $1636 \mathrm{~cm}^{-1}$ showed the N-H bending group of amine. After enzyme immobilization by using cross linker glutaraldehyde, the $\mathrm{NHCO} \cdots \mathrm{CHO}$ bonds reacted to amine groups of enzyme. Therefore some amine groups were coated and the carboxyl groups of enzyme were exposed (as shown in Scheme 1). In the FT-IR spectrum of lipase-bound chitosan magnetic nanoparticles (spectra 5b), the sample showed the broad absorption peak of $\mathrm{OH}$ stretch of carboxylic acid group at $2700-3600 \mathrm{~cm}^{-1}$, indicated that the lipase was successfully bound to the chitosan magnetic nanoparticles.

\subsection{Comparative study of free and immobilized lipase}

The comparative study of free and immobilized lipase was down at different $\mathrm{pH}$ and temperatures using p-nitrophenyl palmitate as a chromogenic substrate. The effect of $\mathrm{pH}$ on the activity of both free and the immobilized lipase was checked in the $\mathrm{pH}$ range of $5-8$ at $40^{\circ} \mathrm{C}$ (Table 1).
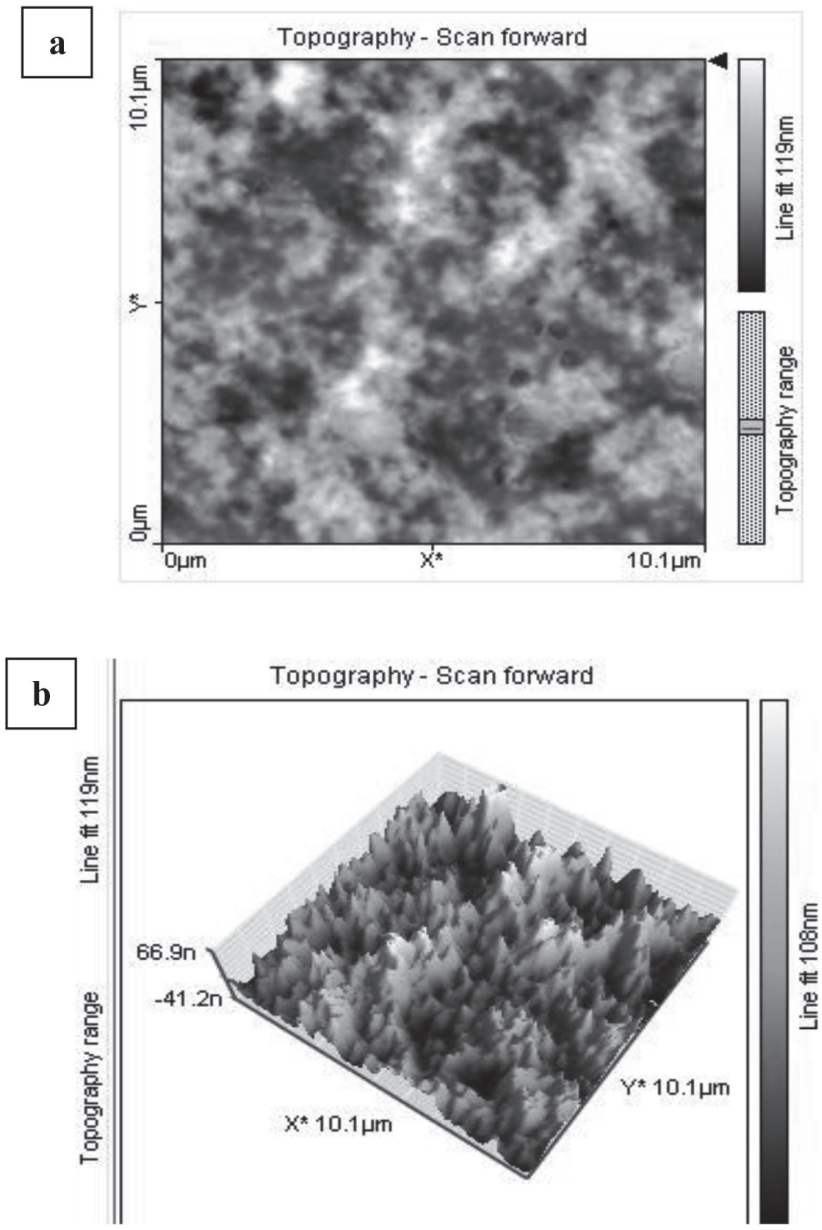

Fig. 3 Topography of chitosan nanoparticles with AFM a) two-dimensional, b) three-dimensional.

The maximum activity was measured at $\mathrm{pH} 7$ with free lipase. In contrast, when the enzyme was immobilized, the

Size Distribution by Intensity

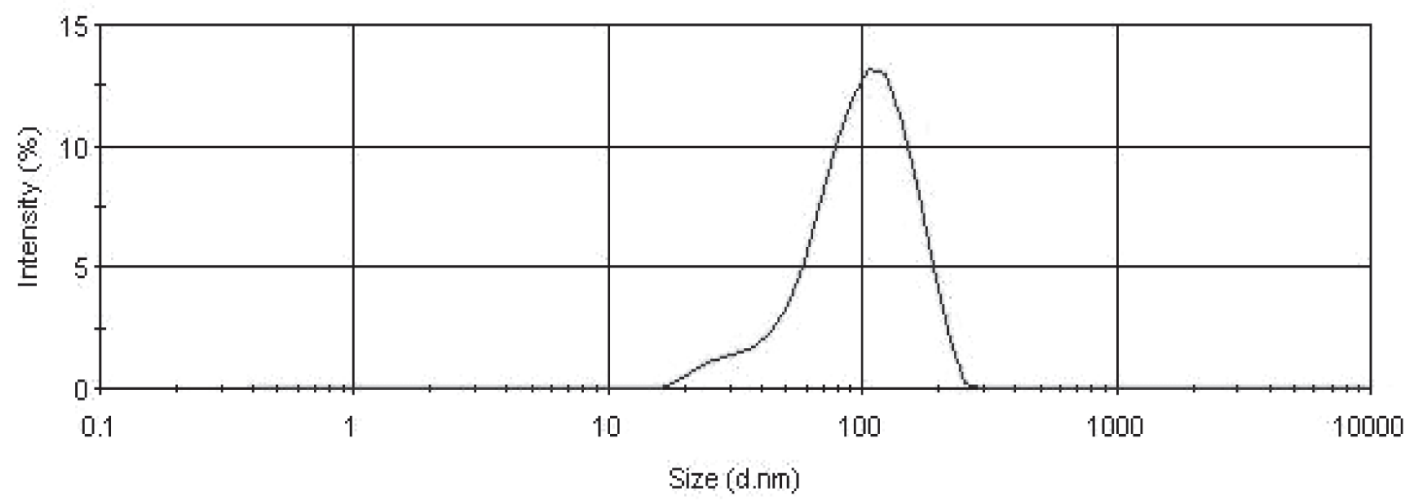

Record 179: Size - installation test 1

Fig. 4 Distribution of CMNP's by Zetasizer. 

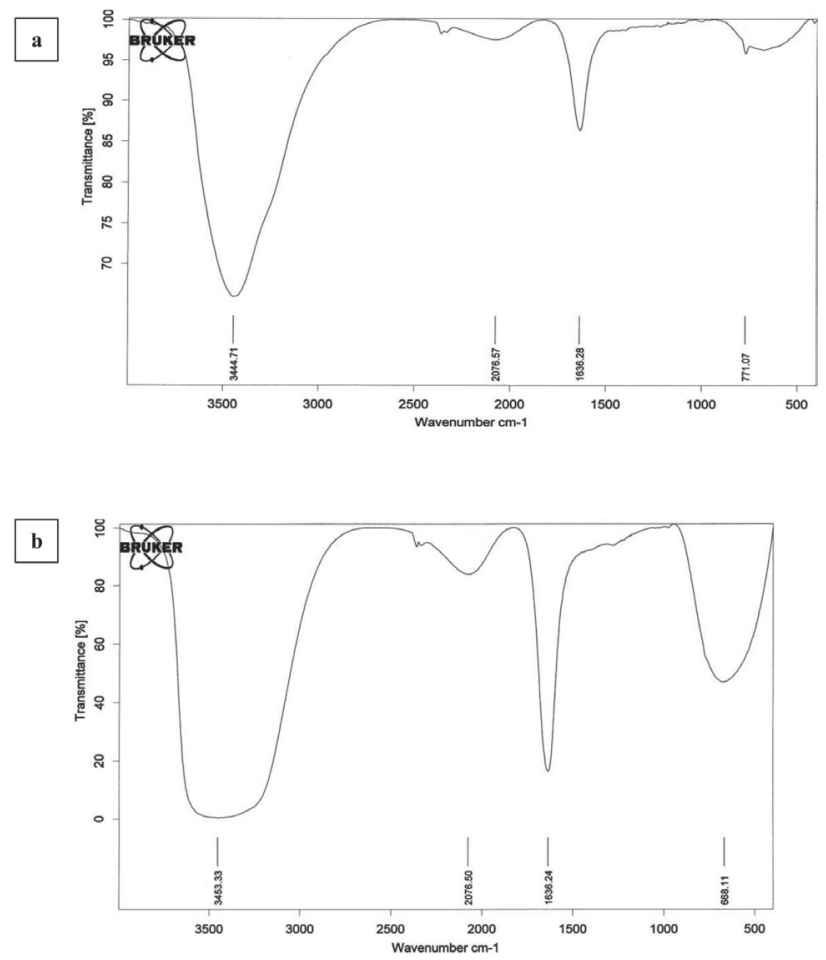

Fig. 5 FTIR spectra of a) chitosan magnetic nanoparticles, b) chitosan magnetic nanoparticles after lipase immobilization.

optimum $\mathrm{pH}$ was shifted to $\mathrm{pH}$ 7.5. A shift of the optimum $\mathrm{pH}$ value from 6 to 7 upon immobilization of Candida rugosa lipase onto porous chitosan beads was also observed by Pereira et $a l .{ }^{26)}$. A change of the optimum $\mathrm{pH}$ for porcine pancreatic lipase entrapped in carragenan beads was previously reported ${ }^{27)}$. Ghamgui et al. reported the maximum activity of free lipase of Rhizopus oryzae at $\mathrm{pH}$ $8^{28)}$. In contrast when the enzyme was immobilized, the optimum $\mathrm{pH}$ was shifted to $\mathrm{pH} 7$.

The optimal temperature dependence of the hydrolysis reaction of pNPP with the free and the immobilized lipases was studied. As shown in Table 2, the optimal temperature for both was $40^{\circ} \mathrm{C}$ (temperature range from $20^{\circ} \mathrm{C}$ to $60^{\circ} \mathrm{C}$ ). It was observed that increasing the temperature from 20 to $40^{\circ} \mathrm{C}$ increased concomitantly the activity of both free and immobilized lipases (Table 2 ). At $40^{\circ} \mathrm{C}$, this activity reached its optimal value of 25.13 and $32.43 \mathrm{IU} / \mathrm{mg}$ with the free and the immobilized lipases, respectively. Therefore, the optimum temperature for both free and immobilized lipases was found to be $40^{\circ} \mathrm{C}$. Beyond $40^{\circ} \mathrm{C}$, the immobilized lipase seemed interestingly to display higher activities than the free one. Ghamgui et al. reported that the optimum temperature for the free and immobilized lipases was $37^{\circ} \mathrm{C}^{27)}$. Montero et al. observed a slight shift in the optimal temperature from 45 to $50^{\circ} \mathrm{C}$ after immobilization of $C$. rugosa lipase on Accurel ${ }^{29)}$. Hiol et al. reported that the optimum temperature for the immobilized Rhizopus oryzae on Amberlite IRC 50 was $35^{\circ} \mathrm{C}^{30)}$. Immobilization of lipase improved total relative activity of the enzyme about $22 \%$ at the optimal temperature. Furthermore, the activity was increased at higher temperature $\left(50\right.$ and $\left.60^{\circ} \mathrm{C}\right)$ showing the enzyme stability significantly improved.

The kinetic parameters of $\mathrm{V}_{\mathrm{m}}$ and $\mathrm{k}_{\mathrm{m}}$ were obtained 1.07 $\mathrm{U} / \mathrm{mg}$ and $29.43 \mathrm{mM}$ for free B. cepacia lipase and $1.29 \mathrm{U} /$ $\mathrm{mg}$ and $25.82 \mathrm{mM}$ for immobilized lipase on CMNPs in presence of $p$-nitrophenyl palmitate as substrate of lipase enzyme, respectively (Fig. 6). Ratio of $V_{m}$ to $K_{m}$ was defined the catalytic efficiency of enzyme. This ratio for free and immobilized lipase was determined as 27.50 and 20.2, showing decrease of activity of enzyme due to immobilization.

\subsection{Biodiesel production}

Transestrification reaction was performed using free and immobilized lipase based systems S1, S2, S3, S4 and S5. In $\mathrm{S} 1, \mathrm{~S} 2$ and S5 systems, transesterification reaction of rice bran oil was carried out by Novozym 435 , free lipase and $B$. cepacia lipase immobilized on CMNPs, respectively. S3 and S4 were performed in presence of soybean oil by using free

Table 1 Effect of $\mathrm{pH}$ on the activity of free and immobilized lipase at $40^{\circ} \mathrm{C}$ (Mean $\pm \mathrm{SD}, \mathrm{IU} / \mathrm{mg}$ Enzyme).

\begin{tabular}{lccccccc}
\hline \multicolumn{1}{c}{$\mathrm{pH}$} & 5.0 & 5.5 & 6.0 & 6.5 & 7.0 & 7.5 & 8.0 \\
\hline Free & $19.32 \pm 1.85$ & $22.03 \pm 1.97$ & $24.12 \pm 2.33$ & $25.94 \pm 2.24$ & $31.45 \pm 2.39$ & $25.07 \pm 2.42$ & $22.86 \pm 1.05$ \\
Immobilized & $17.11 \pm 1.64$ & $20.42 \pm 1.75$ & $23.37 \pm 2.02$ & $26.83 \pm 2.92$ & $30.22 \pm 2.54$ & $32.06 \pm 2.37$ & $25.14 \pm 1.22$ \\
\hline
\end{tabular}

Table 2 Effect of temperature on the activity of free and immobilized lipase (Mean \pm SD, IU/mg Enzyme).

\begin{tabular}{lccccc}
\hline \multicolumn{1}{c}{$\mathrm{T}\left({ }^{\circ} \mathrm{C}\right)^{*}$} & 20 & 30 & 40 & 50 & 60 \\
\hline Free & $18.03 \pm 1.66$ & $22.35 \pm 2.15$ & $25.13 \pm 2.09$ & $11.77 \pm 1.64$ & $5.40 \pm 0.98$ \\
Immobilized & $25.73 \pm 1.44$ & $29.05 \pm 2.89$ & $32.43 \pm 2.22$ & $25.19 \pm 2.33$ & $16.59 \pm 1.90$ \\
\hline
\end{tabular}

*The activity of the enzyme was determined at different temperatures that ranged from $20^{\circ} \mathrm{C}$ to $60^{\circ} \mathrm{C}$ at $\mathrm{pH} 7.5$. 


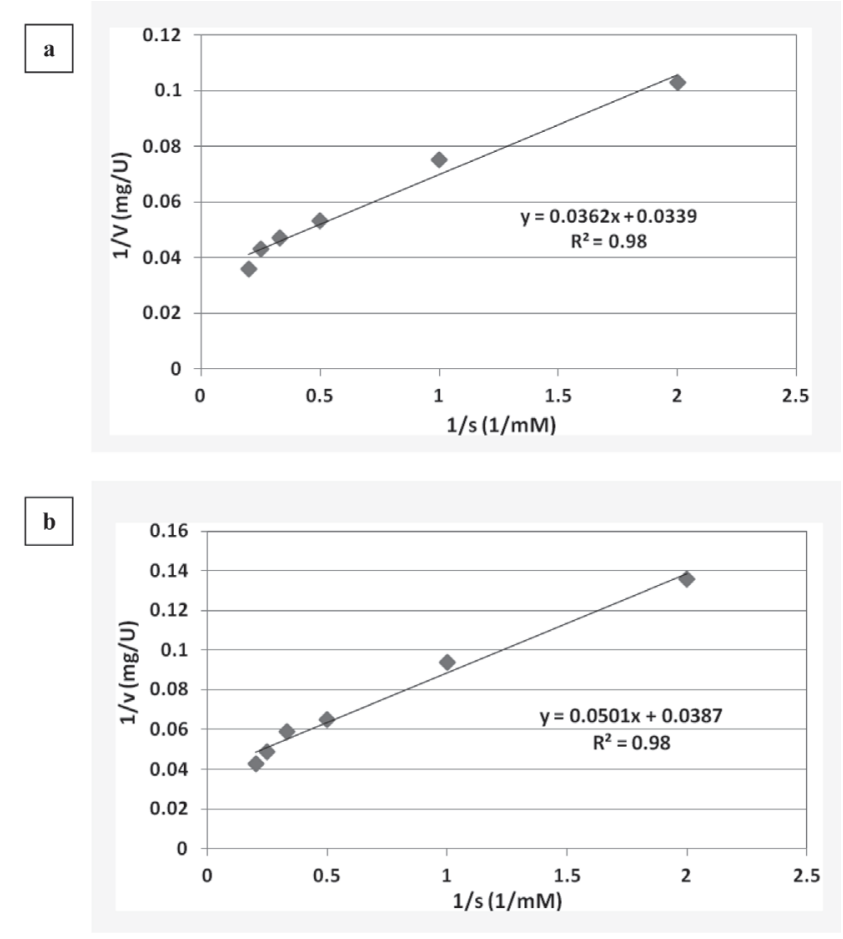

Fig. 6 Lineweaver-Burk plots for a) free enzyme and b) immobilized enzyme on CMNPs in presence of $p$-nitrophenyl palmitate as substrate of lipase enzyme.

and immobilized lipase, respectively. Yield of biodiesel production from these five systems (S1-S5) were $31.90 \%$, $22.54 \%, 28.35 \%, 18.66 \%$ and $18.47 \%$, respectively. The results showed that the enzyme immobilization on CMNPs did not remarkably decrease the activity of lipase. However, the methyl ester content obtained in presence of Novozyme 435 was more than that of CMNP's. This may be due to the cross linker glutaraldehyde which decreases the enzyme activity.

\section{CONCLUSIONS}

The present study investigated the preparation of CMNPs as novel core-shell nanoparticles which was applied for lipase immobilization. Because of magnetic properties of nanomagnets which are located in the core of nanoparticles, separation of nanocarrier by magnet is easily possible. Furthermore, polymeric and hydrophilic properties of chitosan coated as a shell around the magnetic core makes CMNPs as a suitable support for immobilization of the protein lipase by glutaraldehyde. This strong link between lipase enzyme and nanocarrier has an important role in enzyme immobilization and in addition can increase the enzyme absorption rate and enzyme loading.

The results indicated that the biological activity of the enzyme improved while immobilized on CMNPs. We introduce CMNPs as a novel and suitable support for enzyme immobilization for different applications in the field of biotechnology, biomedicine and environment because they are cost effective, easy to prepare and handle, safe and biocompatible.

\section{Acknowledgment}

This study was financially supported by NIGEB (Project No. 429) and gratefully appreciated by authors. The authors wish to express their gratitude to Dr Evangeline Foronda for proofreading of the manuscript.

\section{References}

1) Sounderya, N.; Zhang, Y. Use of Core/shell Structured Nanoparticles for Biomedical Applications, Recent Pat. Biomed. Eng. 1, 34-42 (2008).

2) Salehizadeh, H.; Hekmatian, E.; Sadeghi, M.; Kennedy, K. Synthesis and Characterization of Core-Shell $\mathrm{Fe}_{3} \mathrm{O}_{4^{-}}$ Gold-Chitosan Nanostructure. J. Nanobiotechnology 10 (2012). doi: 10.1186/1477-3155-10-3.

3) Kang, S. M.; Lee, K. B.; Kim, D. J.; Choi, I. S. Biomimetic Approach to the Formation of Gold Nanoparticle/Silica Core/Shell Structures and Subsequent Bioconjugation. Nanotechnology 17, 4719-4725 (2006).

4) Lee, J.; Han, S.; Hyeon, T. Synthesis Of new Nanoporous Carbon Materials Using Nanostructured Silica Materials as Templates. J. Mater. Sci. 14, 478-486 (2004)

5) Jia, H. F.; Zhu, G.; Vugrinovich, B.; Kataphinan, W.; Reneker, D. H.; Wang, P. Enzyme-Carrying Polymeric Nanofibers Prepared Via Electrospinning for Use as Unique Biocatalysts. Biotechnol. Prog. 18, 1027-1032 (2002).

6) Jia, H.; Zhu, G.; Wang, P. Catalytic Behaviors of Enzymes Attached to Nanoparticles: The Effect of Particle Mobility. Biotechnol. Bioeng. 84, 406-414(2003).

7) Kim, B. C.; Nair, S.; Kim, J.; Kwak, J. H.; Grate, J. W.; Kim, S. H.; Gu, M. B. Preparation of Biocatalytic Nanofibres with High Activity and Stability Via Enzyme Aggregate Coating on Polymer Nanofibres. Nanotechnology 16, S382-388 (2005).

8) Zhi, J.; Wang, Y. J.; Luo, G. S. Adsorption of Diuretic Furosemide on to Chitosan Nanoparticles Prepared With A Water-In-Oil Nanoemulsion System. React. Funct. Polym. 65, 249-257 (2005).

9) Abdel Salam, M.; Makki M. S. I.; Abdelaal, M. Y. A. Prepration and Characterization of Multi-walled Carbon Nanotubes/Chitosan Nanocomposite and its Application for the Removal of Heavy Metals from Aqueous 
Solution. J. Alloys Compd. 509, 2582-2587(2011).

10) Fajardo, A. R.; Lopes, L. C.; Rubira, A. F.; Muniz, E. C. Development and Application of Chitosan/Poly (Vinyl Alcohol) Films for Removal and Recovery of $\mathrm{Pb}$ (II). Chem. Eng. J. 183, 253-260(2012).

11) Xiaoli, L.; Yanfeng, L.; Zhengfang, Y. Preparation of macroporous bead adsorbents based on poly (vinyl alcohol)/chitosan and their adsorption properties for heavy metals from aqueous solution. Chem. Eng. J. 178, 60-68(2011).

12) Ngah, W. S. W.; Teong, L. C.; Hanafiah, M. A. K. M. Adsorption of Dyes and Heavy Metal Ions by Chitosan Composites: A review. Carbohydr. Polym. 83, 14461456 (2011).

13) Chang, S. W.; Shaw, J. F.; Yang, K. H.; Chang, S. F.; Shieh, C. J. Studies of Optimum Conditions for Covalent Immobilization of Candida Rugosa Lipase on Poly (Gamma-Glutamic Acid) By RSM. Bioresour. Technol. 99, 2800-2805 (2008).

14) Mohseni, S.; Najafpour, G. D.; Vaseghi, Z.; Mahjoub. S. Solid State Fermentation of Agricultural Residues for Lipase Production in a Tray-Bioreactor. World Appl. Sci. J. 16, 1034-1039(2012).

15) Kalantari, M.; Kazemeini, M.; Tabandeh, F.; Arpanaei, A. Lipase Immobilisation on Magnetic Silica Nanocomposite Particles: Effects of the Silica Structure on Properties of the Immobilised Enzyme. J. Mater. Chem. 22, 8385-8393(2012).

16) Fan, X.; Niehus, X.; Sandoval, G. Lipases as Biocatalyst for Biodiesel Production. Methods Mol. Biol. 861, 471-483 (2012).

17) Lee, D. G.; Ponvel, K. M.; Kim, S. M.; Hwang, S.; Ahn, I. S.; Lee, C. H. Immobilization of Lipase on Hydrophobic Nano-Sized Magnetite Particles. J. Mol. Catal. B Enzym. 57, 62-66 (2009).

18) Huang, X. J.; Yu, A. G.; Xu, Z. K. Covalent Immobilization of Lipase from Candida Rugosa on to Poly (Acrylonitrile-Co-2-Hydroxyethyl Methacrylate) Electrospun Fibrous Membranes for Potential Bioreactor Application. Bioresour. Technol. 99, 5459-5465(2008).

19) Köse, O.; Tüter, M.; Ayşe Aksoy, H. Immobilized Candida Antarctica Lipase-Catalyzed Alcoholysis of Cotton Seed Oil in a Solvent-Free Medium. Bioresour. Technol. 83, 125-129(2002).

20) Rotková, J.; Šuláková, R.; Korecká, L.; Zdražilová, P.; Jandová, M.; Lenfeld, J.; Horák, D.; Bílková, Z. J. Magn. Magn. Mater. 321, 1335-1340(2009).

21) Nishio, K.; Masaike, Y.; Ikeda, M.; Narimatsu, H.; Gokon, N.; Tsubouchi, S.; Hatakeyama, M.; Sakamoto, S.; Hanyu, N.; Sandhu, A.; Kawaguchi, H.; Abe, M.; Handa,
H. Development of Novel Magnetic Nano-Carriers for High-Performance Affinity Purification. Colloids Surf. B Biointerfaces 64, 162-169 (2008).

22) Beveridge, J. S; Stephens, J. R.; Williams, M. E. The Use of Magnetic Nanoparticles in Analytical Chemistry. Annu. Rev. Anal. Chem. 4, 251-273(2011).

23) Liu, K.; Zhao, G., He, B.; Chen, L.; Huang, L. Immobilization of Pectinase and Lipase on Macroporous Resin Coated with Chitosan for Treatment of Whitewater from Papermaking. Bioresour. Technol. 123, 616-619 (2012).

24) Kordel, M.; Hofmann, B.; Schomburg, D.; Schmid, R. D. Extracellular Lipase of Pseudomonas Sp. Strain ATCC 21808: Purification, Characterization, Crystallization and Preliminary X-Ray Diffraction Data. J. Bacteriol. 173, 4836-4841 (1991).

25) Bradford, M. M. A Rapid and Sensitive Method for the Quantitation of Microgram Quantities of Protein Utilizing the Principle of Protein-Dye Binding. Anal. Biochem. 72, 248-254 (1976).

26) Pereira, E. B.; Castro, H. F.; Moraes, F. F.; Zanin, G. M. Kinetic Studies of Lipase from Candida Rugosa. A Comparative Study Between Free and Immobilized Enzyme on to Porous Chitosan Beads. Appl. Biochem. Biotechnol. 91, 739-752(2001).

27) Desai, P. D.; Dave A. M.; Devi, S. J. Entrapment of Lipase Int K-Carrageenan Beads and its Use in Hydrolysis of Olive Oil in Biphasic System. Mol. Catal. B Enzym. 31, 143-150 (2004).

28) Ghamgui, H.; Karra-Chaabouni, M.; Gargouri, Y. 1-Butyl Oleate Synthesis by Immobilized Lipase from $R h i$ zopus Oryzae: a Comparative Study between N-Hexane and Solvent-Free System. Enzyme Microb. Technol. 35, 355-363 (2004).

29) Montero, S.; Blanco, A.; Virto, M. D.; Landeta, L. C.; Agud, I.; Solozabal, R. Immobilization of Candida Rugosa Lipase and Some Properties of the Immobilized Enzyme. Enzyme Microb. Technol. 15, 239-247 (1993).

30) Hiol, A.; Jonzo, M. D.; Rugani, N.; Druet, D.; Sarda, L.; Comeau, L. C. Purification and Characterization of an Extracellular Lipase From a Thermophilic Rhizopus Oryzae Strain Isolated From Palm Fruit. Enzyme Microb. Technol. 26, 421-430 (2000).

31) Wu, Y.; Wang, Y.; Luo, G.; Dai, Y. In situ Preparation of Magnetic $\mathrm{Fe}_{3} \mathrm{O}_{4}$-Chitosan Nanoparticles for Lipase Immobilization by Cross-Linking and Oxidation in Aqueous Solution. Bioresour. Technol. 100, 3459-3464 (2009). 